\title{
Gender Differences and Work-Related Communication in the UAE: A Qualitative Study
}

\author{
Kamarul Zaman Ahmad ${ }^{1}$ \\ ${ }^{1}$ College of Business Administration, Abu Dhabi University, United Arab Emirates \\ Correspondence: Kamarul Zaman Ahmad, College of Business Administration, Abu Dhabi University, Abu \\ Dhabi PO Box 59911, United Arab Emirates. E-mail: drkamphd@yahoo.com
}

Received: January 12, $2014 \quad$ Accepted: January 28, $2014 \quad$ Online Published: February 21, 2014

doi:10.5539/ijbm.v9n3p185 URL: http://dx.doi.org/10.5539/ijbm.v9n3p185

\begin{abstract}
-Purpose-The purpose of the research is to investigate the true nature of any differences between men and women, in the way that they communicate at the workplace.
\end{abstract}

-Design/methodology/approach-A qualitative research was carried out using semi-structured interview questions, involving $418 \mathrm{UAE}$ nationals comprising of 218 Emirati males and 200 Emirati females ranging from the age of 20 years to 55 years.

-Findings-Findings partially supported Tannen (1990) and Gray (1992), but also had some new interesting revelations, unique to the UAE such as regarding communication straightforwardness and tone, group communication, communicating with other nationalities, body Language, forming opinions, expressing them and receiving feedback, openness, disclosure and details in explaining things, conversation topics, and ability to convince others in a sales presentation.

-Research limitations/implications-When making conclusions from a limited sample size, some stereotyping is indeed inevitable.

-Practical and social implications-This research provides valuable insights to anyone who wishes to work and do business in the UAE, from the perspective of gender differences and gender interaction.

- Originality/value Research and publications about gender differences and gender-related communication are abundant in the west. Many statements by some authors such as Tannen (1990) and Gray (1992) are somewhat controversial. On the other hand, research regarding gender-related differences in the UAE is relatively scarce (Alkhateeb, 2001). Since the 9/11 incident, there have been generalisations and negative stereotypes about Arab men, Islam and gender roles in the Middle East. This research is timely, especially in the light of the fast rate of development in the UAE brought about by the discovery of oil in the 1960's and more women entering the workforce.

Keywords: gender differences, United Arab Emirates, work behaviours, communication

\section{Introduction}

Gender in the Middle East is a popular topic but one that is laden with generalisations about Arab men, Islam and gender roles. Negative stereotypes are particularly evident in media since 9/11 (Russell, 2012). This research intends to portray a more accurate, balanced and less emotional view to not only gender differences, but also inter-gender and intra-gender relations in the UAE. This is important because negative expectations that are biased by the beliefs about a particular gender can affect performance of that gender (Ridgeway, 1993). For example, women who are exposed to stereotypical ideas about poor performance of females on math tasks, perform less well on math assessments. That is why research need to be conducted in the UAE, in order to dispel negative stereotypes of both men and women. "Things are changing, girls are less shy about talking to men. That's a good thing because you have to talk to them at university and if you want a career, you have to do that sometimes" said a teenage girl in a study by (Crabtree, 2007, p. 582).

Historically, women were disadvantaged when trying to find work because of their educational background. This should not have been the case since Islam, the official religion in the UAE, has always called for equal access to education for males and females (Gender differences in mathematics achievement among high school 
students in the United Arab Emirates, 1991-2000, 2001), and that means that men should never have enjoyed more priority in education than women.Nowadays, "more female students are enrolled in all levels of education" in the Arab states (Bahgat, 1999, p. 134). (Culture, Gender and the Influence of Social Change amongst Emirati Families in the United Arab Emirates, 2007)commented that girls' schools exhibited higher quality of teaching and classroom practices more conducive to learning, than the boys' schools. The interdependency between families in the past is evidently lacking in the modern metropolitan life in the UAE, according to one respondent in the qualitative study by (Culture, Gender and the Influence of Social Change amongst Emirati Families in the United Arab Emirates, 2007). The older generation of women had found themselves retreating exclusively into their homes, where they are unable to work because of lack of opportunities for education during their generation. However, the current generation of younger women now need to find work and assert their stature commensurate with their education and ambition (Culture, Gender and the Influence of Social Change amongst Emirati Families in the United Arab Emirates, 2007). There are increasing numbers of Emirati females in schools and universities, and consequently in the workplace. Women in the UAE are now needed to carry out the task of nation-building and hold offices and positions in the Government, similar to their counterparts in the West. Consequently, the nature of the interaction between Emirati men and women, as well as the differences in communication styles of the two genders in the UAE workplace, need to be investigated.

\section{Literature Review}

There are many studies on gender and the sociology of gender. The Women in Development (WID) and Gender and Development (GAD) are two frameworks within feminist approaches to development. WID emerged as an effort to include women in the development discourse (Maslak, 2008). This represented a shift from focusing on women in their roles within the family, to their roles as working employees within the organisation. This approach has been criticised for overemphasising the individual without sufficient consideration of context i.e., it looks at women simply being included into existing institutions without understanding the complexity of the relations between men and women (Introduction-From denouncing gender inequities to undoing gender in education: Practices and programmes toward change in the social relations of gender, 2009). GAD emerged as an apparent answer to this criticism. GAD framework considers social structures and includes the examination of the relationship between men and women rather than merely looking at women in isolation (Bannon et al., 2006). A combination of the two approaches is taken in this study.

There have been many publications on gender issue and related topics, judging from a computer search on Psychological Abstracts via PsycINFO.Many statements by some authors such as (Tannen, 1990) and Gray (1992) are somewhat controversial. One area that has received little attention is the gender-related differences in the UAE (Gender differences in mathematics achievement among high school students in the United Arab Emirates, 1991-2000, 2001) especially in the light of fast rate of development brought about by the discovery of oil in the 1960's. In order to understand the issues that Emirati women may now be facing (WID approach), and the complexity of the inter-gender relations (GAD approach) in the UAE, one needs to first look at the literature from the west.

\subsection{Gender Differences in the West}

There are numerous researchthat have been conducted and published about gender differences and gender-related communications in the West.Meta-analyses have been published on the impact of gender on intelligence testing (Cross-Cultural Comparison of Sex-Related Differences on Intelligence Tests: A Meta-Analysis, 1987), cognitive ability including mathematical, verbal and spatial ability (Hyde, 1981; Hyde, Fennema \& Lamon, 1990; Linn \& Peterson, 1985), personality development (Cohn, 1991; Feingold, 1994), conformity and social influence (Cooper, 1979; Eagly \& Carli, 1981; Johnson \& Eagly, 1989), self-disclosure (Dindia \& Allen, 1992), leadership style, evaluation and effectiveness (Eagly \& Johnson, 1990; Eagly \& Karau, 1991; Eagly, Makhijani \& Klonsky, 1992; Eagly, Karau \& Makhijani, 1995), aggressive behavior (Eagly \& Steffen, 1986; Hyde, 1984) and social behavior (Eagly \& Wood, 1991; Wood, 1987).

The idea that women and men have different communication styles have become the theme of many best-selling books on gender differences such as the book written by Gray (1992) titled "Men are from Mars, Women are from Venus". This book argues that there are significant and consistent differences in communication styles between men and women, expressing the notion of gender differences and propagating stereotypes.Tannen (1990) declared that scholars and individuals must acknowledge that men and women communicate differently. Gray (1992) may have taken Tannen's (1990) propositions further by declaring that men and women not only communicate differently, but they have so little in common as to be from completely different planets-struggling to comprehend one another.An important justification for this research is that Gray (1992) himself did not claim 
to have conducted any scientific research and his pronouncements are based purely on his theory and not supported by empirical research (Wood et al., 1998). Among the topics discussed by researchers in the West, are as follows:

\subsubsection{Working with Others}

There are several important topics pertaining to the alleged differences in communication and the working styles of men and women that were highlighted by Gray (1992). Gray (1992) suggested that men prefer to do things by themselves, tend to evaluate the competence of others when interacting, and are more competitive. This is somewhat consistent with some research that have shown that men tend to value male input over female input and assume that men are more competent than women (Martin, 1996; Pierce, 1995; Williams, 1995).Males are also more likely than females to intentionally withhold information to further their own positions or harm another's position (Gender differences in the intentional use of information in competitive negotiations, 2000). Eagly and Karau (1991) found that in short-term and task oriented situations, men are more likely to emerge as leaders, whereas women are more likely to emerge as leaders if the situation calls for more social leader.This is consistent with an earlier meta-analytic study by Wood (1987). This is also supported by a subsequent study by Eagly, Karau and Makhijani (1995) which found that men were more effective than women in roles that were defined in more masculine terms, and women were more effective than men in roles that were defined in less masculine terms. Eagly and Steffan (1986) found that men have a tendency to aggress more than women where that aggression produced pain or physical injury, and notwhen aggression produced psychological or social harm. Women, more than men, perceived that enacting aggressivebehaviorthat would produce pain or physical injury, would harm not only the target, but oneself in the form of guilt and anxiety. It is suggested by Eagly and Steffan (1986) that sex differences in aggression are a function of perceived consequences of aggression that are learned as aspects of gender roles and other social roles.

\subsubsection{Emotions, Self-Worth and Other Personality Attributes}

Gray (1992) states that, women are completely at the mercy of their hormones. "From early adolescence through adulthood, women are twice as likely as men to experience depression" Hoeksma (2001, p. 173). They may not have high self-esteem despite their accomplishments.With regard to the Big Five Personality Dimensions, "women reported themselves to be higher in Neuroticism, Warmth and Openness to Feelings, whereas men were higher in Assertiveness and Openness to Ideas" (Costa, Terracciano \& McCrae, 2001, p. 322). Feingold (1994) found that females were higher than males in extraversion, anxiety, trust, and, especially, tender-mindedness (e.g., nurturance). There were no noteworthy sex differences in social anxiety, impulsiveness, activity, ideas (e.g., reflectiveness), locus of control, and orderliness.Gilligan (1982) asserted that women measure everything in terms of relationships, and men measure in terms of logic.Males were found to be more assertive and had slightly higher self-esteem than females. Hyde (1981) commented that although there may be differences between male and females in terms of intelligence (verbal ability, quantitative ability, and visual-spatial ability), these differences were small. The same goes for verbal ability (Hyde \& Linn 1988).

\subsubsection{Asking Questions and Agreeableness}

Women are more likely than men to ask questions and agree with others, and women are less likely than men to challenge others' statements and frame others' arguments (Gray, 1992). Women have greater concern for cooperation and connection in their relationships. Men are more likely to interpret messages according to levels of dominance, whereas women are more likely to interpret them according to levels of supportiveness. Eagly and Carli (1981) also found that women are more likely to be persuaded than men and are more conforming. An earlier meta-analysis by Cooper (1979), however, had inconclusive results.

\subsubsection{Directness}

Women are often indirect in their communication. They often use tagged phrases like "don't you think" following the presentation of an idea, "if you don't mind" following a demand or "this may be a silly idea, but" preceding a suggestion. Several studies have shown that women tend to soften their demands and statements, whereas men tend to be more direct (Coates, 1989; Tannen, 1990; Spender, 1980; Case, 1994).

\subsubsection{Problems}

According to Gray (1992), women talk about their problems in order to have a connection with others. They don't seek a solution to their problem. Men on the other hand, often try to solve their problems on their own, and if they are not able to, they will discuss their problems with others and expect solutions to be given to them. The problem arises when women talk about their problems to men-men will offer solutions, when the women only want to have an emotional connection. Similarly, problems occur when men talk to women about their 
problems-men want solutions, but only get emotional support from the women.

\subsubsection{Personal Details}

Women converse about topics of a more personal type such as their family, their emotions, and their friendships. Women are also not afraid to embed details in their speech in order to involve people in the events being described. Men, however, use more abstract communication, speaking in vague and general terms (Kramarae \& Treicher, 1983; Schaef, 1985). Dindia and Allen's (1992) meta-analysis on sex differences in self-disclosure concurred with previous findings that women disclose more than men. However, they also pointed out that this is only true in same-sex dyads. When talking with men, women do not disclose any more than their male partners disclose.

\subsubsection{Studies Done in Other Countries}

In Japan, a quantitative study revealed that in gender-mixed formal interactions, female guests are more assertive than male guests. However, the qualitative results show a much more complex picture; domineering and cooperative strategies are used by both, male and female participants (Tanaka, 2009). One possible view regarding this apparent contradiction is that a qualitative research can elicit more information (and is therefore better) compared with a quantitative one, when complex issues are involved.

In Taiwan, it was found that female science teachers in secondary schools perceived greater collegiality among the teachers. This may be due to women's emphasis on emotional connection at work. Male science teachers, on the other hand perceived lower work pressure and better teacher-student relations (Huang \& Fraser, 2009), probably due to men's emphasis on solving problems, and moving on.

In Netherlands, a study by Harskamp, Ding \& Suhre (2008) revealed some rather interesting findings in relation to female students inability to work with the the opposite gender. It was discovered that female students in mixed gender groups did not learn to solve physics problems as well as male partners or as female students in all-female dyads. Analyses of interactive behaviours showed that female students in the mixed gender groups devoted less time actively seeking solutions and spent more time asking questions than their male partners. Female students in the all-female dyads did not differ in interactive behaviour or post-test performance from males. They had a more balanced interactive style than females in the mixed-gender dyads (Harskamp, Ding \& Suhre, 2008).

In Malaysia, Ahmad (2012) found that out of 23 statements made in the first book by Gray (1992) about gender differences,only 8 were supported, 10 were not supported and 5 were actually true for the opposite gender. Ahmad (2012) also found that 6 out of 10 statements derived from a subsequent book written by Gray (2002) were supported, and 4 were not supported. It would appear that the propositions by Gray $(1992 ; 2002)$ about gender differences in the West are not externally valid, and do not apply to some societies in the Far East such as Malaysia. It would therefore be interesting to carry out a study about gender differencesof UAE nationals, and see how much they resemble (or not) with studies done in the West, includingTannen (1990) and Gray (1992; 2002).

\subsection{Domestic Roles in the UAE}

Although this study is primarily about work roles and behaviours, domestic roles can have a spill-over effect. Crabtree (2007) conducted a study in the UAE and found that the autonomy of men in comparison with the constraints on women, was openly acknowledged during the interviews of older women "I would like to have been born a man because men have more freedom. Women stay at home but generally cannot go anywhere." For a married woman, her time is likely to be spent predominantly within the environment of the home. While unmarried girls may assist their mothers in the kitchen, the affluence of families has removed the burden of many of the other household tasks from the shoulders (Crabtree, 2007, p. 581). Most Emirati families now have domestic maids (some more than one per household). "Today a girl can become educated but they don't learn to cook or care for babies" (Crabtree, 2007, p. 583). Shopping for food provisions in many families is undertaken by men as part of their duties of representing and handling family business in the external environment, thus preventing women from interacting with strangers (Crabtree, 2007). However, women can always be seen at shopping malls, usually without their husbands, at the jewellery, cosmetics and clothing departments.

On the other hand, according to Gray (1992), men in the United States of America are encouraged to help with domestic tasks on an occasional basis strictly as a method of "keeping her love tank full and the score even" (Gray, 1992, p. 186). This is clearly an indication that there are significant differences in gender roles between the West and Middle East, as perceived by scholars. This warrants research to be done in the UAE, in relation to gender differences. 


\section{Methodology}

Ethnography is committed to the study of people within everyday environment of human interaction. In order to properly understand the phenomenon, one should not use mechanistic and quantitative approaches, where the production of replicable results is the main aim (Hammersley, 1990). Ethnographic studies typically rely on in-depth interviewing, semi-structured or unstructured approach to asking questions (Burgess, 1995). Recurrent phenomena begin to form conceptual clusters, which then becomes the findings of the study (Brewer, 2000), and this is common in action research. Although the sample size may be small compared with the population, this is compensated by the richness of the qualitative data obtained through extensive interviewing techniques (Brett, 2002; Crabtree, 2007). Furthermore, unlike the study by Klein, Wain and Radnell (2009), where not all of the respondents were Emiratis, the current study involved only Emiratis.

In light of the above, the qualitative method was chosen for this study. A total of 76 masters students from three separate classes in the College of Business in Abu Dhabi University, participated in the initial stage of the study. These students who were themselves Emiratis, formed teams of around 3 to 5 team members and they took turns interviewing each other. The topics of interview are the gender differences in communication styles and behaviours of Emiratis, with emphasis on work group settings. Each of these students then interviewed another 4 to 5 persons each, from outside the university. This amounted to a total of about 342 subsequent interviews. The final sample is therefore around 418 respondents comprising of 218 Emirati males and 200 Emirati females ranging from the age of 20 years to 55 years. The reason for restricting to this age group is that people older than 55 and younger than 20 were not representative of the Emirati working population in the UAE. The masters students, were themselves, ranging from the same age group of 20 to 55 years.

Each team of students then compiled a list of 10 differences between males and females in communications, styles and behaviours, with emphasis on work group settings. The author conducted content analyses on the students' lists, and then compiled his own list as follows: any item pertaining to gender differences which werementionedin at least three of the teams' lists, wereidentified and compiled by the author. The findings are described under the next heading.

The students by coincidence, all lived in the Emirates of Abu Dhabi, but their respondent interviewees came not only from this region, but also the neighbouring Emirates of Dubai, Sharjah and Ajman, thereby increasing the representativeness of the sample.

\section{Findings}

\subsection{Communication Straightforwardness and Tone, and Group Communication}

Men appear to be very direct and come to the point very quickly. In group meetings, they are often the first to speak and do not hesitate to share their opinions or ideas. Women are shy in group communication and they may either be silent or find a female colleague to chat with. Women prefer to converse in a more round about way and refer to matters indirectly. Men are also not hesitant to use abusive terms and harsh language when they speak with their friends and colleagues. On the other hand, women tend to use cleaner language and do not use abusive language. They usually keep their tone quite polite while speaking with others.

\subsection{Communicating by Phone}

It is common for women to use the phone to talk to her friends or family for long periods (sometimes more than one hour), where they discuss many subjects, interests, problems and issues. They also use computer applications like Twitter, what's-app, and facebook. On the other hand, men generally make much shorter calls on the phone, and they prefer face-to-face meetings. Women may also use the phone in order to avoid conflict, whereas males have no problem communicating face-to-face.

\subsection{Communicating with Other Nationalities}

Emirati women are more open to other nationalities and are more comfortable having conversations with them, but they are shy towards Emirati men. This is especially obvious at the workplace where the women can comfortably chat with their male colleagues from other nationalities, but they will stop talking as soon as an Emirati male appears on the scene. This is because of the traditional upbringing in the UAE that emphasises on gender segregation at schools and universities. However, both genders feel that inter-gender communication at work in permissible if it related to work, but purely social interaction between the genders especially outside of the workplace, is against the local customs and the religion of Islam.

\subsection{Body Language}

Usually men pay attention to the speaker and their eyes are looking at that person to show him/her that he is 
listening. Women tendnot to make eye contact because of shyness and culture boundaries, especially when the other person involved is an Emirati male. Shaking hands between the genders is not allowed by custom and religion.

\subsection{Forming Opinions, Expressing Them and Receiving Feedback}

Men usually form opinions about things, or about other people. Usually their observations and statements are honest about how they see it, rather than what others think about it. They express it as they see it, and sometimes they do not care about the impact of their words on other people's feelings. They seem to talk first, then think about how their words may impact others emotionally. Women on the other hand tend to form an opinion, only after knowing what their friends and family think about it. They tend to go with the consensus, rather than having an individualistic opinion. Also, when women form their opinion, they are more sensitive about expressing them. They take time to think before talking, as they tend to care about how others would feel about their opinions. Similarly, they can feel offended in many ways, even from a simple statement. They take things more personally when it comes to a disagreement. Men on the other hand are less sensitive, and are more able than women to receive negative feedback.On the whole, men are more rational and task-oriented, compared with women.

\subsection{Expressing Emotions}

Males tend to keep their own personal feelings and moods to themselves and refrain from expressing them. Females on the other hand are direct about their own personal feelings and moods and do not hesitate to tell them to their partners, especially when they are upset. They can even cry in public. In this respect, both genders are similar to their counterparts in the West.

\subsection{Listening and Engagement in Conversation}

Males are often not good listeners. Men have short attention spans and do not show much interest in listening to others, especially if personal matters are being discussed. They get bored easily and do not hesitate to do other things like sending text or emails with their mobiles, while someone else is speaking. Women show a great deal of engagement while talking and listening to others. Women tend to give their $100 \%$ attention while listening to others, and show interest in what others are saying. They tend to keep eye contact when listening and acknowledge what is being said.

\subsection{Sharing and Solving Problems}

Men tend not to share their personal problems with people. If some of them do, they share it with their close friends, rather than with their families. Men usually take the logical approach to solving problems. They tend to keep their emotions aside and deal with the issue more logically. Women tend to share their problems with their friends and family. In fact, they seek support and sympathy from them. Women get emotional when faced with problems, and this affects their ability to solve problems on their own. They tend to rely on others to help them solve their issues and are afraid to take bold steps. In solving problems, women like to share their experiences and ask questions, whereas men prefer to provide information and solutions. In this respect, both genders are similar to their counterparts in the US.

\subsection{Openness, Disclosure and Details in Explaining Things}

Men are not likely to share their personal information with others like, their wealth, job, business or such matters. If they do share them, they do soamong their close friends. Women on the other hand tend, to discuss everything and anything with their friends and family, and do not feel the need to be secretive. Women are more detailed in their conversations than men, explaining everything. For example, if she went to someone's wedding party, she will talk about every single event and thing which happened in the party. She will talk about her dress, make-up, other attendees, as well as the food. However, a man will only say that he went to his friend's wedding party, and it was good.

\subsection{Multi-Tasking}

Men prefer to do one thing at a time, whereas women are more likely to do multiple things simultaneously such as listening to music, reading, and using the cell phone.

\subsection{Conversation Topics at Work (and Outside)}

Women often talk about their problems, fashion, medical issues, beauty and talk about people. Men usually talk about cars, business, hobbies, and make fun of some of their friends. 


\subsection{Ability to Convince Others in a Sales Presentation}

Men have very domineering personalities especially when trying to convince others. This is because they have the courage to talk to both genders. When they do, they usually provide facts and proofs. For example, if a man is a salesperson in a perfumes store, he will sell the product easily to the customer, as he would tell the customer that the item is the most popular, that many customers have bought it, and there is only one left. On the other hand, women feel shy in such situations and might not try to convince the customer,and just say to him or her "It's up to you."Also, in the UAE society, men's words are believed to be more trustworthy, compared with the women's.

\section{Discussions and Implications}

In terms of expressing emotions and sharing and solving problems, both Emirati men and women exhibit similar behaviours to their counterparts in the West. However, this research has also revealed many new and interesting findings, unique to the UAE. All of the findings in this study can be of great assistance to whoever wishes to work and do business in the UAE. The implications of the findings are explained below.

\subsection{Communication Straightforwardness and Tone, and Group Communication}

Because men are very direct and come to the point very quickly, communications with them should also be brief and direct to the point. Circuitous conversations will likely demotivate and confuse them. As men tend to speak up in meetings and the women prefer to remain silent, efforts should be made to make the women share their ideas with the rest of the group. This is especially so when they have already begun conversing with other women and sharing their ideas with them. The leader or facilitator of a group meeting should encourage such women to share their views with the entire audience, rather than with just their close friends. This is a good way to elicit valuable suggestions that would probably not be heard under the usual conditions. Men should also be admonished if they use abusive terms and harsh language when they speak with their friends and colleagues during meetings or in general work settings, in order to maintain a sense of professionalism. In this regard, the practice of women who tend to use "cleaner" language should be emulated. The facilitator should keep his or her tone polite while speaking with others, and also expect everyone else to do the same.

\subsection{Communicating by Phone}

Do not communicate for long periods on the telephone, especially if the person at the other end is a female. Face-to-face communication is better when there is a situation that is sensitive, or that has the potential to result in conflict. Men would have no problems with such face-to-face communication. On the other hand, when dealing with women face-to-face, be prepared that they do not make eye contact with you, and their communication be circuitous.

\subsection{Communicating with Other Nationalities}

A male expatriate (as compared with a male Emirati) would probably have an easier time communicating with other Emirati women at work.However, Emirati women should not be pressed into continuing the conversation when an Emirati male appears on the scene. Perhaps, the Emirati woman may suddenly change her conversational style and appear less friendly. The male expatriate should be respectful of the UAE culture and not try to get friendly with the Emirati female. Male expatriates should also not invite Emirati females to go out and have coffee or dinner, as purely social interaction between the genders especially outside of the workplace, is against the customs and religion of Islam.

\subsection{Body Language}

When talking to men, one should make eye contact to show him that one is listening. Expect women not to make eye contact because of shyness and culture boundaries, especially when there is an Emirati male on the scene. Men should not shake hands with the women, as this is not allowed by local custom and religion.

\subsection{Forming Opinions, Expressing Them and Receiving Feedback}

If one wishes to start a group discussion or elicit honest opinions from others, one should first ask the men as they are more straightforward and tell it like it is, whereas women tend to form an opinion, only after knowing what their friends and family think about it. One should take care when speaking to women as they can feel offended in many ways, even from a simple statement. They take things more personally when it comes to a disagreement. Men on the other hand are less sensitive, and are more able than women to receive negative feedback. So, discussions with men can be done on a task-oriented style, whereas discussions with women should be on a relationship-oriented style. 


\subsection{Expressing Emotions}

Males will probably have to be asked to tell you how they feel whereas women will not hesitate to tell you, especially when they are upset. Take care when discussing emotionally charged issues, as women can create a scene in public.

\subsection{Listening and Engagement in Conversation}

Males are probably not a good choice to unload one's personal grievances and problems, as they tend not to be good listeners. Men have short attention spans and do not show much interest in listening to others, especially if the personal matters are being discussed. They get bored easily, so do not be alarmed when they start doing other things like sending text or emails with their mobiles when one is speaking. The opposite can be said about women as they show a great deal of engagement while talking and listening to others. They tend to give their 100 per cent attention while listening to others and show interest in what others are saying.

\subsection{Sharing and Solving Problems}

What Emirati men and men in the USA have in common is the tendency not to share their personal problems with other people. In the UAE, when men do decide to share it with others, they choose to do so with their close friends, rather than with their families. So expatriates, males or females, should not be surprised if the male Emirati colleague does not confide in them. In fact, the Emirati males may even appear somewhat aloof to them.

What Emirati women and women in the USA have in common is the tendency to share their problems with their friends and family. They in fact seek support and sympathy from them. An expatriate should therefore not be surprised if Emirati women confide in them. They sometimes get so emotional when faced with problems, that this affects their ability to solve problems on their own. However, the aim of conversation at this stage is not to give solutions but rather to lend a sympathetic ear.

\subsection{Openness, Disclosure and Details in Explaining Things}

An expatriate should not expect Emirati men to volunteer their personal information with others like, their wealth, job, business or such matters, without being asked specifically. Women on the other hand tend to discuss everything and anything with their friends and family and do not feel the need to be secretive and thus make much better conversational partners on these topics. Emirati men on the other hand, appear aloof.Also women are more detailed than men in explaining things. If one wishes to find out about what happened in a social event, ask the women for they will give you more details. Men on the other hand will simply say that it was good or bad, and say nothing more.

\subsection{Multi-Tasking}

When an Emirati man seems to be focussed on something, it is best not to interrupt them, as they prefer to do one thing at a time. Women on the other hand are quite capable of doing multiple things such as listening to music, reading, and using the cell phone, at the same time.

\subsection{Conversation Topics at Work (and Outside)}

Expect Emirati women to talk about their problems, fashion, medical issues, beauty and talk about other people. When Emirati men get together, expect their conversations to be about cars, business, hobbies, and making fun of some their friends.

\subsection{Ability to Convince Others in a Sales Presentation}

Emirati men will probably make better salespeople than Emirati women. This is due to the men's more dominating personalities when trying to convince others. When it comes to sales, Emirati men have more courage to talk to both genders, and they usually haveevidence and proofs to back up their claims. On the other hand, women may be equally effective salespeople if the environment calls for non-aggressive and non-domineering behaviour. The Emirati woman salesperson would simply say "It's up to you." However, the Emirati women salesperson should learn to provide evidences whenever they are trying to convince others as, in the UAE society, men's words are believed to be more trustworthy compared with the women's.

\section{Limitations}

The limitations that apply to qualitative research such as subjectivity, interviewer bias, inaccuracy, lack of objectivity, transparency and replicability, etc. all apply to this study. Furthermore, there are some scholars who argue that researchers may be guilty of gender stereotyping if they makegeneralised statements that men behave in one way, and women behave in another (Eisenberg, Martin, \& Fabes, 1996). The insinuation that these behaviours and characteristics are inherent and constant is also known as essentialising (Wood, 1993). Wood 
(2001) objects to efforts to essentialise women and men, in particular the assertion that communication styles are innate and unchangeable. It is not the intent of the author to essentialise and stereotype in this paper. Rather, it is the intention of the author to point out that negative stereotypes about both men and women in the West, and about the stereotypes held by the West regarding men and women in the middle east, especially the UAE, areinaccurate. Furthermore, the research was done using a qualitative approach (rather than quantitative) involving 418 respondents comprising of 218 Emirati males and 200 Emirati females, mostly spread throughout the UAE. The Emirati respondents were given the freedom to express what they themselves perceive, and not be constrained by rigid statements in a questionnaire formulated by researchers from the West. This article is intended to be a rough guide for people wishing to work or do business in the UAE, from the perspective of gender-related communication. However, one should always realise that, in the end, these are just generalisations and these statements do not apply to every individual Emirati, male or female.

\section{References}

Ahmad, K. Z. (2012). An empirical test of the propositions by Gray and Tannen relating to Gender communication in Malaysia. Asian Social Science, 8(11), 250-263.

Alkhateeb, H. M. (2001). Gender differences in mathematics achievement among high school students in the United Arab Emirates, 1991-2000. School Science and Mathematics, 101(1), 5-9. http://dx.doi.org/10.1111/j.1949-8594.2001.tb18184.x

Bahgat, G. (1999). The Persian Gulf at the Dawn of the New Millennium. New York: NOVA Science Publishers.

Bannon, I., \& Correia, M. C. (2006). The other half of Gender: Men's issues in Development. Washington, DC: The Word Bank.

Born, M., Bleichrodt, N., \& Van der Flier, H. (1987). Cross-Cultural Comparison of Sex-Related Differences on Intelligence Tests: A Meta-Analysis. Journal of Cross Cultural Psychology, 18, 283-314. http://dx.doi.org/10.1177/0022002187018003002

Brett, J. (2002). Th experience of disabilityfrom the perspective of parents of children with profound impairment: Is it time for an alternative model of disability? Disability \& Society, 17(7), 825-843. http://dx.doi.org/10.1080/0968759022000039109

Brewer, J. D. (2000). Ethnography. Buckingham: Open University Press.

Burgess, R. G. (1995). In the field: An introduction to field research. London/New York: Routledge.

Case, S. (1994). Gender differences in communications and behaviour in organisations. In M. J. Davidson, \& R. J. Burke (Eds.), Women in Management: Current Research Issues (pp. 144-163). London: Paul Chapman Publishing.

Coates, J. (1989). Women's speech, women's strength? York Papers in Linguistics, 13, 65-76.

Cohn, L. D. (1991). Sex Differences in the Course of Personality Development: A Meta-Analysis. Psychological Bulletin, 109, 252-266. http://dx.doi.org/10.1037/0033-2909.109.2.252

Cooper, H. M. (1979). Statistically Combining Independent Studies: A Meta-Analysis of Sex Differences in Conformity Research. Journal of Personality and Social Psychology, 37(1), 131-146. http://dx.doi.org/10.1037/0022-3514.37.1.131

Costa, P. T., Terracciano, A., \& McCrae, R. (2001). Gender Differences in Personality Traits across Cultures: Robust and Surprising Findings. Journal of Personality and Social Psychology, 81(2), 322-331. http://dx.doi.org/10.1037/0022-3514.81.2.322

Crabtree, S. A. (2007). Culture, Gender and the Influence of Social Change amongst Emirati Families in the United Arab Emirates. Journal of Comparative Family Studies, 34(4), 575-587.

Deal, J. J. (2000). Gender differences in the intentional use of information in competitive negotiations. Small Group Research, 31, 702-723. http://dx.doi.org/10.1177/104649640003100604

Dindia, K., \& Allen, M. (1992). Sex differences in self-disclosure: A meta analysis. Psychological Bulletin, 112, 106-124. http://dx.doi.org/10.1037/0033-2909.112.1.106

Eagly, A., \& Carli, L. (1981). Sex of Researchers and Sex-Typed Communications as Determinants of Sex Differences in Influenceability: A Meta-Analysis of Social Influence Studies. Psychological Bulletin, 90, 1-20. http://dx.doi.org/10.1037/0033-2909.90.1.1 
Eagly, A., \& Johnson, B. T. (2008). Gender and Leadership Styles: A Meta-Analysis. Psychological Bulletin, 233-256.

Eagly, A., \& Karau, S. J. (1991). Gender and the Emergence of Leaders: A Meta-Analysis. Journal of Personality and Social Psychology, 60, 685-710. http://dx.doi.org/10.1037/0022-3514.60.5.685

Eagly, A., \& Steffen, V. J. (1986). Gender and Aggressive Behavior: A Meta-Analytic Review of the Social $\begin{array}{lllll}\text { Psychology } \quad \text { Literature. } & \text { Psychological } & \text { Bulletin, } & \text { 330. }\end{array}$ http://dx.doi.org/10.1037/0033-2909.100.3.309

Eagly, A., \& Wood, W. (1991). Explaining Sex Differences in Social Behavior: A Meta-Analytic Perspective. Personality and Social Psychololgy Bulletin, 17, 306-315. http://dx.doi.org/10.1177/0146167291173011

Eagly, A., Karau, S. J., \& Makhijani, M. G. (1995). Gender and the Effectiveness of Leaders: A Meta-Analysis. Psychological Bulletin, 117, 125-145. http://dx.doi.org/10.1037/0033-2909.117.1.125

Eagly, A., Makhijani, M. G., \& Klonsky, B. G. (1992). Gender and the Evaluation of Leaders: A Meta-Analysis. Psychological Bulletin, 111, 3-22. http://dx.doi.org/10.1037/0033-2909.111.1.3

Eisenberg, N., Martin, C., \& Fabes, R. (1996). Gender development and gender effects. In Berliner \& R. Calfee (Eds.), Handbook of educational psychology (pp. 358-396). New York: Prentice Hall.

Feingold, A. (1994). Gender Differences in Personality: A Meta-Analysis. Psychological Bulletin, 116, 429-456. http://dx.doi.org/10.1037/0033-2909.116.3.429

Gilligan, C. (1982). In a different voice. Cambridge MA: Harvard University Press.

Gray, J. (1992). Men are from Mars and women are from Venus: A practical guide for improving communication and getting what you want in your relationship. New York: Harper Collins.

Gray, J. (2002). Mars and Venus at the Work place: A practical guide for improving communication and getting what you want in your relationship. New York: Harper Collins.

Hammersley, M. (1990). Reading Ethnographic Research: A critical Guide. London: Longman.

Harskamp, E., Ding, N., \& Suhre, C. (2008). Group composition and its effect on female and male problem-solving in science education. Educational Research, 50(4), 307-318. http://dx.doi.org/10.1080/00131880802499688

Hoeksema, S. N. (2001). Gender differences in depression. Current Directions in Psychological Science, 173-176. http://dx.doi.org/10.1111/1467-8721.00142

Huang, S. Y., \& Fraser, B. J. (2009). Science Teachers' Perceptions of the School Environment: Gender Differences. Journal of Research in Science Teaching, 46(4), 404-420. http://dx.doi.org/10.1002/tea.20284

Hyde, J. S. (1981). How Large are Cognitive Gender Differences? A Meta-Analysis using Omega2 and D. American Psychologist, 36, 892-901. http://dx.doi.org/10.1037/0003-066X.36.8.892

Hyde, J. S., \& Linn, M. C. (1988). Gender Differences in Verbal Ability: A Meta-Analysis. Psychological Bulletin, 104, 53-69. http://dx.doi.org/10.1037/0033-2909.104.1.53

Hyde, J. S., Fennema, E., \& Lamon, S. J. (1990). Gender Differences in Mathematics Performance: A Meta-Analysis. Psychological Bulletin, 107, 139-155. http://dx.doi.org/10.1037/0033-2909.107.2.139

Johnson, B. T., \& Eagly, A. (1989). Effects of Involvement on Persuasion: A Meta-Analysis. Psychological Bulletin, 106, 290-314. http://dx.doi.org/10.1037/0033-2909.106.2.290

Kramarae, C., \& Treicher, P. (1983). Gender, language and the workplace: an exploratory study. Women in Management Review, 22(4), 319-336.

Linn, M. C., \& Peterson, A. C. (1985). Emergence and Characterization of Sex Differences in Spatial Ability: A Meta-Analysis. Child Development, 56, 1479-1489. http://dx.doi.org/10.2307/1130467

Martin, P. Y. (1996). Men, masculinities and management: Gendering and evaluating dynamics. In Men as managers, managers as men: Critical perspectives on masculinity (pp. 186-209). London: Sage Ltd.

Maslak, M. (2008). Introduction: The Structure and Agency of Women's Education. Albany New York: State University of New York.

Ridgeway, C. (1993). Gender, status, and the social psychology of expectations. In P. England (Ed.), Theory on Gender/Feminism on Theory. New York: Walter de Gruyter. 
Russell, C. D. (2012). Gender, academic achievement and meanings of schooling in Ras al Khaimah, United Arab Emirates. New York: Columbia University.

Schaef, A. (1985). Women's Reality: An Emerging Female System in a White Male Society. San Francisco, CA: Harper \& Row.

Spender, D. (1980). Man Made Language. London: Routledge and Kegan Paul Ltd.

Stromquist, N., \& Fischman, G. (2009). Introduction - From denouncing gender inequities to undoing gender in education: Practices and programmes toward change in the social relations of gender. International Review of Education, 55(5-6), 463-482. http://dx.doi.org/10.1007/s11159-009-9146-z

Tanaka, L. (2009). Communicative stances in Japanese interviews: Gender differences in formal interactions. Language \& Communication, 29(4), 366-382. http://dx.doi.org/10.1016/j.langcom.2009.03.001

Tannen, D. (1990). You Just Don't Understand: Women and Men in Conversation. New York: William Morrow.

Williams, C. L. (1995). Still a man's world. Berkeley, CA: University of California.

Wood, W. (1987). Gender and moral voice: From woman's nature to standpoint theory. Women's Studies in Communication, 53-71.

Wood, W. (1987). Meta-Analytic Review of Sex Differences in Group Performance. Psychological Bulletin, 102, 53-71. http://dx.doi.org/10.1037/0033-2909.102.1.53

Wood, W. (2001). A critical response to John Gray’s Mars and Venus portrayals of men and women. The Southern Communication Journal, 67(2), 201-211. http://dx.doi.org/10.1080/10417940209373229

Wood, W., \& Dindia, K. (1998). What's the difference? A dialogue about differences and similarities between men and women. Mahwah, NJ: Lawrence Erlbaum Associates.

\section{Copyrights}

Copyright for this article is retained by the author(s), with first publication rights granted to the journal.

This is an open-access article distributed under the terms and conditions of the Creative Commons Attribution license (http://creativecommons.org/licenses/by/3.0/). 